\title{
Health and pathology: a brief history of the biopolitics of US mathematics education
}

\author{
Ryan Ziols $^{1}$ (D) $\cdot$ Kathryn L. Kirchgasler ${ }^{2}$ (D)
}

Accepted: 1 September 2021/ Published online: 20 October 2021

(c) The Author(s), under exclusive licence to Springer Nature B.V. 2021

\begin{abstract}
Concerns about health and disease have long pervaded mathematics education research, yet their implications have been underappreciated. This article focuses on three contemporary relationships amplified by the COVID-19 pandemic: (1) school mathematics and national health, (2) mathematics educators' roles in distinguishing the health needs of students, and (3) mathematics instruction as either enhancing or threatening students' mental health and social adjustment. We argue that these concerns are foundational preoccupations of mathematics education research that have persistently shaped debates over who should learn mathematics, how, and to what ends. Our study examines histories of school mathematics and health discourses to explore how particular notions of health entered US mathematics education during the 19th and early twentieth centuries in ways that resonate with recent research trends and responses to COVID-19. We especially attend to how health/pathology distinctions reconfigured hierarchies of nationality, sex, race, and dis/ability within exclusionary, segregated, colonial, and tracked mathematics instruction. By mapping some of the shifting contours of health and pathology over time, we emphasize the potential dangers of the pandemic reanimating long-circulating dividing practices, such as in emerging trends comparing national metrics of well-being, responding to perceived trauma with differentiated instruction, and seeking to calibrate healthy mathematics identities in marginalized groups.
\end{abstract}

Keywords Biopolitics $\cdot$ Mathematics education $\cdot$ Body studies $\cdot$ Affect $\cdot$ Diversity $\cdot$ Equity

\section{Introduction}

Health has long been a concern in education. The current pandemic, however, has thrown health inequities into stark relief. Alongside tremendous suffering, COVID-19 has spotlighted the politics of formulating problems (e.g., climate change, gun violence, and white supremacy) as pandemics or public health emergencies. What might this mean for mathematics education? Despite its conventional framing as a neutral subject—cold, abstract,

Ryan Ziols

rziols@gsu.edu

1 Georgia State University, GA, Atlanta, USA

2 University of Wisconsin-Madison, WI, Madison, USA 
and disconnected from the body and body politic - school mathematics has frequently sought to promote children's physical, mental, and social well-being, especially for groups designated as at risk. While mathematics education scholars have scrutinized assumptions about "at-risk" groups (Larnell et al., 2016; Martin, 2019) and turned critique to systemic health inequities (Tate, 2008), questions of how health concerns have shaped the problem space of mathematics education have been left unasked. This article explores how distinctions of health and pathology have been dynamically interwoven with mathematics education for over two centuries. We aim to open dialogue about the implications of these historical traces for issues of injustice today.

Our investigation builds on scholarship unsettling conventional views of mathematics education as a self-contained field focused on learning a discrete subject. The incorporation of mathematics in schooling, the formation of mathematics education as a field of study, and the differentiation of mathematics instruction for target populations are historical artifacts embodying non-neutral modes of knowing and being in the world (Bullock, 2020; Martin, 2019; Pais \& Valero, 2012). Our article contributes by examining how health distinctions are neither incidental to school mathematics, nor novel to the present moment. Seldom has attention been given to the centrality of health discourses in mathematics education efforts to protect, restore, or optimize the well-being of the child, community, population, or nation.

Whereas previous scholarship has long critiqued the production of racializing, gendering, classed, and ableized hierarchies through Euro-centric school mathematics (e.g., Berry, 2021; d'Ambrosio, 2003), little scholarship has examined how these amalgams have been made possible through mutating health and pathology concerns. These include attempts - always partial and contested - to differentially preserve the health of (non-)citizens, supervise the hygiene of target populations, and ensure all students acquire a healthy appreciation for school mathematics to avoid a feared cultural decline. Importantly, mathematics education has not simply overlooked the well-being of distinct groups or populations. Rather, as we examine below, disperse claims to improve the health of individuals and populations have also helped constitute hierarchical typologies of students and school mathematics.

To pursue our argument, this paper historicizes three long-standing preoccupations with health/pathology: (1) how school mathematics must change to preserve national health, (2) how mathematics educators should distinguish and administer to the health needs of student populations, and (3) how mathematics instruction can either enhance or diminish students' mental health and social adjustment. With the USA as our focal point, we use a Foucauldian analytic of biopower to highlight how these preoccupations have relied on historically dynamic premises of healthy bodies and affect that reconfigured hierarchies of nationality, sex, race, and dis/ability within exclusionary, segregated, colonial, and tracked mathematics instruction.

For example, early 19th-century school mathematics became a site to protect the nation's health by weighing hopes for the mental cultivation of future citizens with worries over disrupting their mind-body-spirit balance. Exclusionary restrictions on mathematics study rested on pathologies presumed to differ primarily along lines of precocity, sex, and hereditary background. By the turn of the twentieth century, mathematics educators were increasingly tasked to promote 'instructional hygiene' by diagnosing health needs according to presumed individual and group differences. By the 1930s and 40s, mental hygiene discourses merged with modern personality metrics to array pupils on trajectories of psychosocial adjustment, with ability tracking and therapeutic instruction promising to remedy differences feared to erode democracy and appreciation for mathematics as Western 
civilization. Together, these changes have given rise to a dispersed field of strategic possibilities (Foucault, 1972) — potentialities available today when health concerns are again foregrounded in mathematics education.

We organize our argument as follows. First, we sketch three concerns evident in mathematics education responses to the COVID-19 pandemic and outline how a biopolitical lens and historicizing methodology can spotlight premises underlying these concerns and their implications for questions of exclusion and normalization. We then examine the three historical shifts outlined above-illustrating how health concerns have iteratively reconfigured hierarchical trajectories distinguishing who was to learn mathematics, how, and to what ends. In concluding, we return to the present to question what is at stake when inherited notions of health and pathology remain embedded in and constitutive of mathematics education research. For over two centuries, we argue, school mathematics has straddled fears of harm and injury with hopes for children's health and well-being in ways that have created and sustained hierarchies of human difference that are underappreciated in research today.

\section{Prevailing mathematics education responses to the pandemic}

At present writing, public policy and academic responses to COVID-19 continue, with new information about novel coronavirus variants and their starkly uneven impacts. Rather than attempt to characterize this ongoing situation, we spotlight three themes from US and transnational responses regarding how health appears as a problem for school mathematics to address. Our analysis included prominent mathematics education journals (e.g., Educational Studies in Mathematics, Journal for Research in Mathematics Education, Journal for Mathematical Behavior, ZDM), US-based position statements (e.g., National Council for Teachers of Mathematics [NCTM] and National Council for Supervisors of Mathematics [NCSM], 2020), and webinars (e.g., NCTM's 100 Days of Professional Learning). The themes highlight different but overlapping approaches to reorient school mathematics toward pressing health concerns.

\subsection{National health and decision-making}

First, responses invoked hopes that enhancing mathematics-informed critical thinking could improve health-related decision-making. That is, mathematics education promises to strengthen the reasoning of children and adults as a strategy to prevent illness and facilitate social change. In the early months of the pandemic, researchers argued that if the public were more mathematically literate, they would better understand predictive models of disease spread and appreciate the need for mask wearing to 'flatten the curve' (Kim et al., 2020; Soland et al., 2020). Recommended strategies included having children examine graphs comparing infection rates and study the geometry of social distancing circles (Barnes et al., 2020; Lammers et al., 2020; Yoon et al., 2021). Beyond immediate concerns to stop the virus, hopes for addressing larger societal problems impacted by COVID19 have posited mathematical reasoning and critical thinking as keystones for generative social change (Engelbrecht et al. 2020; NCTM and NCSM, 2020; Stephan et al., 2021).

Of course, hopes and fears of developing healthy decision making and vital reasoning capacities in future citizens through school mathematics are not new (Cohen, 1999; Popkewitz, 2008). Early 19th-century hopes of producing better reasoners were counterbalanced 
with fears that overstudy of mathematics could induce ill health and insanity. And, as we later explore, changing coordinates of health and pathology have reinstated demographic divisions in measuring children's proximity to normative ideals of mathematical reasoning-projecting some as threats to national vitality.

\subsection{Distinguishing health needs of student populations}

A second response has called mathematics teachers to minister to health-related concerns, including health inequities related to ongoing histories of marginalization. Amid fears about the developmental and economic impacts of lost instructional time, scholars have also argued that the pandemic opens possibilities to make mathematics more relevant by centering on health concerns and the differential traumas experienced by students (Barnes et al., 2020; NCTM \& NCSM, 2020; Stephan et al., 2021; TODOS, 2020; Yoon et al., 2021). Educators and researchers are called upon to determine students' health-related needs, coupled with worries that online learning and the displacement of traditional metrics could make it difficult for teachers to "diagnose and respond to students' levels and needs" (Bakker \& Wagner, 2020, p. 2). Efforts to address racialized educational and health disparities through mathematics instruction vary in their consideration of school mathematics as a promising site for closing various gaps and/or as a source of perpetuating extant inequities. Nonetheless, a shared premise in such research is that mathematics education for marginalized groups should be oriented to their everyday lives to enhance student engagement, make mathematics more meaningful, and cultivate positive social change (Berry, 2021; Borba, 2021; Engelbrecht et al., 2020; Leyva, 2021; NCTM \& NCSM, 2020; Santana et al., 2021; TODOS, 2020; Wagner et al., 2020).

Efforts to diagnose students' learning and health needs also draw from 19th- and 20th-century histories, such as targeted reforms to protect the health and hygiene of the body politic. As early as the 1830 s, hopes for creating social change through mathematics instruction have traveled with fears that some minds or bodies might necessitate a different educational approach. While health-related concerns have changed, hopes for more responsive school mathematics to assumed (and often racialized) hierarchies of need are frequently tied to differential pedagogical strategies and interventions.

\subsection{Enhancing students' mental health and social adjustment}

Third, throughout the pandemic, immediate health and safety concerns have become interspersed with concerns for how mathematics instruction could affect students' social, emotional, and/or mental health and the need to help students readjust socially. Researchers have urged mathematics educators to prioritize their students' mental health, while also noting the field's own histories of injury such as generating anxieties, harming children's self-concept, and failing to support all students in developing healthy mathematics identities (Berry, 2021; Dykema et al., 2020; Leak et al., 2021; NCTM \& NCSM, 2020; TODOS, 2020).

Concerns about interactions between physical health and psychological, mental, or social pathologies also have long histories in school mathematics. In the early nineteenth century, educators were urged to monitor pupils' mind-bodyspirit balances to avoid general illness and insanity. By the twentieth century, fears of populations losing interest in school mathematics combined with new metrics of physiological, psychological, and social maladjustment to locate students on a spectrum of normal to abnormal mental hygiene. 
It became possible to delineate student categories as needing distinct research methods to understand them and different instructional tiers to respond to their assumed affective states.

Taken together, the three themes-i.e., national health and decision-making, distinguishing health needs, and enhancing mental health - differ in their premises of what new responsibilities COVID-19 places on mathematics educators and researchers. All, however, posit the pandemic as a novel reckoning for the field that warrants new research agendas and pedagogical priorities. Undoubtedly, many aspects of this public health crisis are unprecedented and require thoughtful responses. A danger lies in self-evident notions of health that make reform agendas appear medically and morally necessary. It is precisely through this sense of self-evidence that problematic historical traces may be perpetuated or reanimated-conserving old logics and creating new divisions within efforts to include.

\subsection{Researching research: extant critiques of health/pathology logics in mathematics education}

To pursue our claims, we build on Pais and Valero's (2012) call for researching research. Drawing on analytics of biopower and biopolitics (Foucault, 1990, 2003; Rabinow \& Rose, 2006; Weheliye, 2014), we examine how research operates as a productive site for truth discourses linking mathematics education to theories of health and pathology. While biopolitics has been taken up in heterogeneous ways within mathematics education (de Freitas, 2017; Kollosche, 2016; Llewellyn, 2018; Pais, 2019), our interest is in how research draws on truth regimes that prescribe conditions for social change, diagnosis, and intervention. These conditions can be understood as forms of governance premised on securing the health of individuals, populations, and nations (Rabinow \& Rose, 2006) that include and exceed their racialized and colonial antecedents (Weheliye, 2014). This is not to suggest that research (or governance) is simply 'good' or 'bad.' Attention is directed instead at the cultural politics of mathematics education (Valero, 2018) as a dynamic site for fostering (and in the process, fabricating) certain kinds of people (Popkewitz, 2004) in our case, how naturalized health/pathology distinctions locate populations at varying distances from normalcy and well-being.

Before detailing our methodology, we spotlight three lines of inquiry in mathematics education that raise biopolitical questions salient to the themes above. First, scholars have questioned how school mathematics justifies its own use value (Pais, 2013) by treating the acquisition of mathematics skills as self-evident predictors of future well-being and national health (e.g., by producing vital worker-citizens, enhancing technoscientific discovery, or improving national security) (d'Ambrosio, 2003; Kanes et al., 2014; Llewellyn, 2018; Valero, 2018). Second, scholars have questioned how clinical demarcations of learning or health needs enclose categories of students as requiring separate strategies of intervention and surveillance (Bullock, 2020; Diaz, 2017; Yolcu, 2019). These studies question how bodies are differentially scientized, medicalized, and racialized through school mathematics (Pais, 2011; Popkewitz, 2004). Third, scholars have examined how research has tethered subject-specific notions of mental health, identity, and affect to demographic categories in ways that risk dividing students through dynamic appeals to 'identity' formation (Chronaki \& Kollosche, 2019; Diaz, 2021; Valero, 2018; Ziols, 2019).

In sum, a biopower lens provides analytical leverage to consider how even wellintentioned approaches, whether addressing inequities or urgent issues of life and death, rely upon assumptions about what constitutes healthy learning, living, and affect. 
These historical assumptions, embedded in practices of research and pedagogy, remain underexamined in how they create distinctions, localize pathology, and authorize differential treatment. Next, we outline a methodological strategy to explore how pandemic responses are not entirely new and health/pathology distinctions are more intricately intertwined with school mathematics than previously recognized.

\subsection{Historicizing the present}

As a history of the present (Foucault, 1991), our study aims to shake the self-evidence of current ways of thinking and doing by demonstrating some of the historical contingencies making them appear necessary. This approach refuses a linear progress narrative and declines to code present or past in simple binaries of dominance/oppression. Instead, it scrutinizes changing formulations of problems that school mathematics has been recruited to solve (Popkewitz, 2004; Valero, 2018). We consider how hierarchies produced through mathematics education have not only relied upon fixed notions of ability and productivity (Davis \& Martin, 2018) but mobile distinctions of health and pathology that order individuals and groups along trajectories of therapeutic intervention and supervision (Kirchgasler, 2018; Yolcu \& Popkewitz, 2019; see also Cohen, 1983).

Our analysis draws from a larger study of a wide range of sources (e.g., journals, policy statements, and textbooks) to analyze how notions of health have appeared in relation to the aims and methods of US school mathematics. This approach also involved close readings of authors and texts credited with producing notable changes in US mathematics education (e.g., Bidwell \& Clason, 1970), such as Warren Colburn and Pestalozzi in the 1800s, John Dewey, William James, and William Speer in the 1890s, and the NCTM in the 1930s and 40s. We did not attempt a comprehensive account of past periods but read widely across interdisciplinary perspectives, comparing how health discourses were conceptualized in mathematics education versus educational and social science discourses more broadly (e.g., Baker, 2013; Danziger, 1997; Tomlinson, 2005). We then toggled between historical documents and recent scholarship to consider which strategies of diagnosis and intervention have persisted, warranting scrutiny as matters of concern today (Latour, 2004). In subsequent rounds of analysis, we mapped out shifting strategic possibilities (Foucault, 1972) for conceptualizing health in school mathematics, such as efforts to balance the mind-body-spirit, scientize hygiene, or fabricate the modern personality as driving purposes for school subjects and teacher training. We do not aim to present a universalized, generalizable account, but to highlight discourses in the USA (due to our own familiarity and location) with enough specificity to open dialogue and spur further research on the transnational circulation of health and educational interventions.

For this article, we bracketed three shifts that resonate with the themes from our review of pandemic responses: (a) the rise of school mathematics as a site tethered to national health in the early nineteenth century; (b) the differentiation of mathematics education to promote hygiene and happiness at the turn of the twentieth century; and (c) the pre-World War II entrance of mental hygiene discourses (e.g., psychosocial adjustment) and cementing of distinct tiers of school mathematics to address fears of cultural decline. Throughout, we consider how school mathematics has generated modes of demarcating the un/healthy child that contributes to refiguring what constitutes healthy minds, bodies, affect, communities, and nations. 


\section{Cultivating a school mathematics for healthier future citizens}

In the early nineteenth century, mathematics was becoming widely accepted as a school subject for fostering healthy citizens by recruiting "all classes" of (free white) children into liberal self-governance (Cohen, 1999). This development rested on new notions of health and childhood that assembled aims of mental cultivation, bodily health, and moral/spiritual alignment with the values of the US Republic. A nation-based conception of corporeal, mental, and spiritual-moral health rested on new configurations of brains, bodies, social groups, and their relations drawn from phrenology, physiology, vital statistics, medicine, and faculty psychology (Baker, 2013; Tomlinson, 2005). Children were newly understood as especially vulnerable to harm of the mind, body, or spirit and needing pastoral direction and care (Cohen, 1999). As this section explores, health/pathology distinctions began shaping the contours of school mathematics, as purported benefits of mental cultivation were weighed against perceived dangers of destabilizing children's mind-body-spirit balancedangers presumed to differ by precocity, sex, and hereditary background.

Ambiguities of who could or should appear as pupils in US mathematics classrooms involved dynamic ascriptions of national character, whiteness, and proper spheres of activity assigned to each sex. First, mental health reform discourses imbued school mathematics with the power to cause, cure, or prevent insanity (Foucault, 1988; Jenkins, 2010) or even death ("Educating Children to Death", 1837). US scholars feared that improper mathematics instruction could threaten children's health by bringing the insanity epidemic, allegedly ravaging England and France, to American soil (Cohen, 1999; e.g., Brigham, 1833). Second, common schools did not yet involve compulsory attendance, age-graded classrooms, or state-based administration; the gesture to include "all classes" (Monroe \& Colburn, 1912) entailed the exclusion and abjection of most free and enslaved Blacks, indigenous populations, immigrants, and others projected outside the fabricated ideal of (free white) Anglo-Saxon Protestant members of the republic (J. Anderson, 1988; Berry, 2021; Woodson, 1919). Increased concern with securing the health of enslaved peoples (due in part to a 1808 federal law banning 'slave importation'), alongside fears of their resistance to social control, saw a wave of anti-literacy laws prohibiting instruction for Southern Black children; this, coupled with racist attempts to codify their moral, mental, and physical characteristics as predisposed to deviance and requiring violent surveillance, meant that the only mathematics instruction permitted by law, if any, was for completing commercial transactions (Barclay, 2014; Givens, 2020). Third, the fabrication of White citizens provided grounds for producing sex distinctions (Schuller, 2018). School mathematics promised mental cultivation for male citizens (with all the exclusions this entailed) and future mothers deemed capable of passing on that cultivation to the next generation of these citizens (Cohen, 1999; Todd, 1998). That is, girls were to be educated only in so far as their instruction might transfer cultivated mental, physical, and moral characteristics to (white male) offspring via heredity and home teaching (Cohen, 1999; Todd, 1998; Tolley, 2002). In these ways, school mathematics offered to stabilize a presumably fragile US Republic by regulating the transfer of heritable forms of mental cultivation ${ }^{1}$ to distinguish, elevate, and protect the (free white) citizen.

\footnotetext{
1 We use the term "mental cultivation" instead of "mental discipline" because the latter, though also used, was understood in the sense of cultivating or developing a sound mind, body, and moral/heart/soul balance (cf. Stanic, 1986; see Baker, 2013).
} 
Anxieties over mental cultivation and insanity prompted the rise of school mathematics to preserve the nation's health. Following the writings of prominent medical, political, and educational advocate Benjamin Rush, the mind-body-spirit was increasingly understood as interlinked with the health of the body politic via decentralized flows modeled on the circulatory system and regulated by material forces and affective sympathies (Altschuler, 2012; Schuller \& Gill-Peterson, 2020). ${ }^{2}$ Phrenological theories also posited school mathematics as a preventative health strategy, arguing that occupations involving geometry and arithmetic were less likely to produce insanity than those which "naturally excite[d] the feelings" such as priests, poets, lawyers, and actors (Spurzheim, 1836, p. 146). Reformers further assessed one's propensity to insanity via distinctions of climate, sex, race, religion, nationality, and type of governance (Brigham, 1833; see Cohen, 1999; Tomlinson, 2005). Mathematics education reformers cited phrenologists arguing that US citizens' need to manage the increased freedoms and responsibilities of democracy rendered them more vulnerable to insanity than those cast as living either at a secure 'distance from civilization' (Spurzheim, 1836) or under 'despotic rule,' as presumed in China and Russia (Brigham, 1833). Claims of US exceptionalism and the superiority of liberal self-governance, then, were coupled with fears of the fragility of the American experiment-a fragility that school mathematics was to help address.

Mathematics instruction also joined other public health reforms, such as locating schools away from busy cities, protecting classrooms from drafts and dirt, and encouraging movement, cheer, and play (Kett, 1971). Teaching mathematics using pupils' bodies as object study, encouraging hand clapping and foot stomping, and avoiding a loss of interest in the study were strategies to foster mental cultivation and avoid deranging a mind-bodyspirit balance ("Account of the System of Infant Schools", 1826; Dwight, 1835; Goodrich, 1818). The mathematical study of one's own body, when combined with instruction in physiological laws "instituted by God" (Combe, as quoted in Price, 1960, p. 223), offered one site for improving children's health, happiness, and usefulness and protecting against the "disease, pain, and premature death" (p. 226) feared to result from mind-body-spirit imbalances (Brigham, 1833; Tomlinson, 2005). ${ }^{3}$ Preventing imbalances-especially for precocious children considered most vulnerable to brain inflammation-required physical exercise, limited study time, carefully regulated levels of difficulty and abstraction, and, in the case of girls, increased surveillance of propensities for development deemed too masculine or too sedentary (Brigham, 1833; Cohen, 1999; Todd, 1998). Thus, mathematics instruction as a preventative health strategy demanded differential regulation of students' affect, balancing physical and mental exertion, avoiding harms to the precocious, and assessing the levels of abstraction deemed healthy for a given subgroup — all concerns that resonate in new forms today.

\footnotetext{
${ }^{2}$ Rush's perspective marked a break from European influences in arguing for a "new" materialist perspective that treated the mind, brain, and body as a node in decentralized circulatory flows of material forces and affective sympathies, where proper health involved balancing the removal of blockages with the stimulation of deficiencies in social and material flows (Altschuler, 2012).

3 While no one person was held to have the same arrangement of brain faculties and organs, phrenologists posited generalities and differences in ways that both contested and reinserted extant racial, sex, and classbased hierarchies (Todd, 1998; Tomlinson, 2005). For instance, US education leader Horace Mann took the writings of phrenologist George Combe as overturning fixed notions of heredity tied to class distinctions, a new malleability that demanded the improvement of future citizens through a more scientific health education in common schools (Price, 1960; Tomlinson, 2005).
} 
In brief, early 19th-century anxieties about the preventative, curative, or damaging effects of school mathematics centered on future citizens' mind-body-spirit health-providing a foothold for distinguishing individual and social bodies via theories of social and material circulations, heredity, sex, profession, physical activity, nationality, political orientation, religion, and environment. This was a marked difference from the eighteenth century when the brain was not equated with the mind, school mathematics was not intended for children (let alone "all classes," or certain girls), and debates over mathematics education seldom involved health concerns (Cohen, 1999). Yet, by the mid-nineteenth century, school mathematics exemplified the promise of common schooling for promoting the mental cultivation, physical vitality, and spiritual health of the citizenry. It also generated new pathologies that would anticipate the late 19th-century medicalization of childhood and recent efforts to improve national health through extending mathematics "for all."

\section{Adapting school mathematics for hygiene and happiness}

By the early twentieth century, school mathematics became a subject of clinical expertise, with teachers increasingly trained to identify individual and populational differences through a medicalizing discourse of scientific hygiene (e.g., Burnham, 1909; see Petrina, 2006). The rapid expansion of compulsory schooling accompanied the professionalization of the field by adapting instruction via evolutionary logics and new metrics of ability, interest, and needs (Popkewitz, 1987). Emerging fields of microbiology, dietary science, and home economics contributed to novel expectations for citizens to regulate daily habits via scientific problem-solving and mathematical calculation (Kirchgasler, 2018; Yolcu \& Popkewitz, 2019). ${ }^{4}$ Clinical expertise demanded standardizing the mathematics curriculum so classrooms could become experimental sites of prediction and control while securing the safety of the child, race, and nation. The resulting rank-ordering of pupils was understood as serving a democratic goal of promoting social harmony amongst those presupposed as unequal. This section first explores how instructional hygiene permitted the calibration of mathematics pedagogies, and then examines how efforts to overturn binaries of mind/body and intellect/emotion repurposed school mathematics as responsible for differentially generating health, happiness, and democratic participation.

\subsection{Instructional hygiene}

While current events have drawn renewed attention to the 1918 pandemic, the health crisis dominating educational reports of the early 1920s was not a virus, but an alarm that medical and psychometric inspections had designated a large percentage of Armed Forces applicants as physically and mentally unfit (Setran, 2003). School mathematics was enlisted to address these eugenics-inspired fears of race degeneration in publications like Thorndike's (1922) and Burnham's (1924) The Normal Mind. For Burnham, failed army inspections

\footnotetext{
4 As germ theory began to supplant climactic theories of disease, a proliferation of health education campaigns moved between colonial interventions in the Philippines and Puerto Rico and urban and rural communities in the continental US (W. Anderson, 2006; Nieves, 2014). Surveillance of daily habits and housing conditions targeted reservations (Paulet, 2007), immigrant tenements (Bulmer et al., 1991), Mexican, Japanese and Chinese neighborhoods (Gonzalez, 1985; Molina, 2006), and agricultural extension projects targeting women in the rural South and differentiated by race (Domosh, 2015).
} 
revealed that arithmetic tests "proved extremely sensitive to disturbances of social conditions" (p. 385). While noting school subjects in general as disturbed by the war, Burnham posited arithmetic as the most "dislocated" by "virtue of its exacting call on the most delicate functions of the mind" (p. 385). That dislocation was ascribed not just to fatigue, shock, and strain, but also changes in "the sex of teachers" (p. 385)—casting female educators as endangering mathematical instruction and national vitality.

Just as mental testing and medical inspection made feared declines in the fitness of US soldiers newly calculable, techniques to diagnose schoolchildren furnished new possibilities for scientific hygiene of instruction (Rapeer, 1917). Diagnostic pedagogies circulated between comprehensive, segregated, and colonial schools (Coloma, 2009; Kirchgasler, 2018; McLeod \& Paisley, 2018). A new clinical approach demanded teachers take a deskside view resembling the bedside view of the doctor (Petrina, 2006) to diagnose pupils' needs and prescribe instruction. As empirical studies of children's learning and living habits shifted the grounds of potential pathology, school mathematics emerged as a new site of problems (cf. Lundin, 2012). For instance, a growing literature suggested that arithmetic could become a "source of worry" and a "serious menace to health" by producing "nervous disorders" like arithmomania, defined as fidgeting habits acquired from too much engagement with number forms (Burnham, 1911 p. 56). ${ }^{5}$ One scholar exhorted teachers to avert arithmomania and full-blown insanity by de-emphasizing logical arguments in favor of problem-solving situations and by prioritizing "measurable results" (Howell, 1914, p. 112, emphasis original). By tailoring instruction to monitor daily mathematical habits (e.g., meal planning) and using quantitative assessments, mathematics teachers appeared poised not only to alleviate pupils' mental stress but also to realize "the dream of predictive pedagogy" (p. 113).

Preventing pathological habits demanded calibrating instruction along a hierarchy of presumed health needs. For those ascribed immediate needs-whether young children or populations cast as underdeveloped-developing self-regulation through aesthetically pleasing, sensory-based activities was prioritized over logic and abstraction (Rapeer, 1917; Sowell, 1905; Yolcu \& Popkewitz, 2019; Ziols, 2019). ${ }^{6}$ Pedagogies of monitoring domestic habits (e.g., diet, household budgeting) simultaneously moved as strategies of colonial governance in sites like the US-occupied Philippines (Kirchgasler, 2018). Likewise, boarding schools prescribed practical arithmetic to instill a "care for the body" (Reel, 1904, p. 34) and "teach habits of thrift and economy to Indian children" (U.S. Office of Indian Affairs, 1908, p. 135), while segregated Mexican schools in the USA held special parent nights to teach arithmetic alongside "hygienic methods of living" (Gonzalez, 1985, p. 61). Meanwhile, in journals like The Mathematics Teacher, the rank ordering of populations

\footnotetext{
5 Arithmomania embodied a concern for the mental stress assumed to plague ambitious and studious pupils:

Numerical relations fill the mind to the exclusion of more important relations; the subject is truly not sane on this subject, in short, he is a victim of arithmomania. He enumerates everything-counts telegraph poles, boards in the sidewalk, steps in the stairs, trees along the way, etc. And it is known that this mild form of not saneness may develop in times of mental stress into pathological forms, not to be distinguished from true insanity. (Howell, 1914, p. 144).

${ }^{6}$ Habits, deemed essential for mental and moral cultivation (Bennett et al., 2013), provided a common working object for functional and social psychology, public health, eugenics, euthenics, child welfare, and Americanization. School mathematics was upheld as ideal for forging habits of neatness, speed, precision, and accuracy essential for character formation (Green, 1918), as well as "the habit of perseverance in the face of complexity" (Yocum, 1914, p. 155) and the "power to think clearly" (Gentlemen, 1913, p. 25).
} 
via metrics of individual difference was posited as inherently "democratic" (Betz, 1923, p. 469) in securing a more orderly society. Mathematics instruction increasingly aimed to "help children live" and bring "attitudes and practices" in schools "more in harmony with social need" (Green, 1918, pp. 37-38). In these ways, hygienic perspectives, rejecting former problematics of mental cultivation and insanity, relied instead on targeted interventions to help subpopulations appreciate their alleged place in the social organism and its naturalized division of labor.

\subsection{Reconfiguring mind/body and intellect/emotion relations}

Besides calibrating instruction to perceived needs, instructional hygiene sought to promote health and happiness by bridging purported splits of mind/body and intellect/emotion. Mathematics textbooks attempted to bridge the mind and body through sensory training and movement - central objects of study in late 19th-century experimental physiology and psychology owing to American Herbartianist efforts to mathematize perception (Crary, 1988). Consider, for instance, Speer's (1897) well-circulated Elementary Arithmetic textbook that tied hygiene and happiness to sensation and movement:

The aid of sensory and motor activity is to be constantly sought. Far from lessening the bodily power, the school should help to bring all activity into right relations. The dawning powers are fitly nourished through happy experiences which deepen the interest and strengthen the will through right conduct. If hygiene and happiness seem foreign to the teaching of mathematics, the connection should be established. We shall not be successful in teaching any subject if we attempt to separate the thinking being from the being that senses, feels, and acts. (p. 11)

Evident here is a reconfiguration of school mathematics aims. The balancing of mind-body-spirit was exchanged for suturing the "thinking being" and the "being who senses, feels, and acts" to achieve bodily power, hygiene, and happiness-now understood via scientized notions of sensory and motor activity.

Efforts to orient mathematics instruction to emotions were not evenly sedimented. A Teacher's guide in the US-occupied Philippines insisted that arithmetic instruction awaken a "real interest" by crafting everyday problems using local market prices (Theobald, 1907, p. 163) - invoking the racialized premise of these pupils as interested only in utilitarian mathematics. Likewise, architects of industrial schooling (Watkins, 2001) cast racialized populations as needing applied mathematics to overcome an alleged propensity toward emotionality. At the segregated Hampton Institute, Jones (1917) prescribed mathematics problems of daily community life on the premise that "to emotional groups, prone to action without adequate thought, thorough practice in mathematical processes is essential" (p. 49). Differentiated mathematics instruction thus served as a biopolitical strategy to preserve the health of the body politic by neutralizing purported dangers of those racialized as internal threats to the US empire/nation.

In place of phrenological theories, early 20th-century instructional hygiene gave rise to a field of mathematics education that was identified as a modern profession through the adoption of clinical techniques. Those techniques linked the training of perception, movement, hygiene, and interest to recapitulatory scales that imagined trajectories of racial and cultural evolution as mirroring stages of child development. Coupled with clinical metrics were Neo-Lamarckian theories suggesting that the capacities, emotionality, and bodily needs of student populations were differentially modifiable (Schuller, 2018), which 
demanded closer inspection and targeted interventions. As we explore next, scholars in subsequent decades sought to secure the cultural and democratic value of mathematics through novel mappings of personality development along similar recapitulatory trajectories.

\section{Prioritizing a mathematics for social adjustment and cultural preservation}

By the 1930s and 40s, mental hygiene discourses ${ }^{7}$ arrayed students on a developmental scale that interspersed physiological, psychological, and sociological norms of healthy adjustment. School mathematics became charged with promoting the health of democratic society in three novel ways: first, by shoring up an appreciation for the cultural value of mathematics as Western; second, by securing the social order through ability tracking; and third, by using case studies to understand individuals and cultural groups via personality metrics. Hopes of ensuring healthy psychosocial adjustment carried fears particularly directed at populations previously excluded from (post-)secondary education.

The Mathematics Teacher saw the perceived crisis of declining enrollment in high school mathematics courses (Stanic, 1986) as signaling a possible loss of "civilization" (Schaaf, 1930, p. 496). Drawing from Spengler's (1932) Decline of the West, Schaaf argued that threats to school mathematics were also threats to a "culture" (i.e., the West) and its "mathematic" (p. 496). Amidst fears of difference-reflected in immigration quotas and exacerbated by economic depressions, political reversals, and the onset of World War IINCTM Yearbooks upheld school mathematics as a chief instrument of "social progress" (Joint Commission of the Mathematical Association of America [MAA] and the National Council of Teachers of Mathematics [NCTM], 1940, p. 47). Preserving civilization became tied to a pedagogical challenge of instilling an appreciation for mathematics as the root of knowledge that nurtured scientific discovery and a vital democracy (MAA \& NCTM, 1940; see Popkewitz, 2004).

Efforts at fostering mathematical appreciation targeted the new category of "slow learners"- especially as purported health differences became associated with divides between the "mathematically gifted" and the "slow" or "dull normal." In the same MAA and NCTM report (1940), Terman was quoted as claiming that "the gifted excel not only in intellectual traits, such as originality, will power, capacity to persevere, sense of humor, and common sense, but also in physical growth and in general health" (p. 136). That explicit link between mathematical giftedness and improved health marked a shift from 19th-century fears of the precocious as especially vulnerable. Now, academic "retardation" was considered "fundamentally a problem of mental health" as varied theories and metrics classified the "dull normal" as lacking capacities for healthy living, including attention span, imagination, and ability to "detect an absurdity in an illogical statement” (p. 133). While Terman's statement may be read today as leveraging medical discourses to justify segregating students by purported ability and health, it is crucial to recognize that the professionalization of mathematics educators also rested on claims

\footnotetext{
7 Mental hygiene was somewhat of a misnomer. While mental health was a focal point, mental hygiene entailed a scientization of health understood as connected to "every school subject," including lessons in "child hygiene," "motor training," and "physical hygiene" (Burnham, 1924, p. 3). Personality maladjustments came to appear as "the cause of the individual mental disorder and social problems of all sorts" (Cohen, 1983, p. 124).
} 
that rank-ordering and grouping strategies offered a therapeutic good. Recognizing the (presumed) limitations of the "dull normal" promised to instill greater sympathy, as "no teacher" could "read the list" of deficiencies without "having his desire strengthened to reach this group of pupils more effectively" (p. 133). Developmental trajectories thus located the 'dull normal' as perpetually on a lower rung of intellectual competence and health but also as a focal point of attention for the mathematics teacher exhorted to take seriously their suffering, inherent humanity, and potential for self-development.

Finally, reforms began to recruit emotions to bolster student health via novel constructs of calculable personality traits (Cohen, 1983; Danziger, 1997). Volumes like Emotion and Conduct in the Adolescent (Zachary \& Lighty, 1940) urged teachers to jettison Puritan views of emotion:

To some extent, no doubt, the Puritan tradition has been responsible for the tendency in all Anglo-Saxon cultures paradoxically both to discount emotion and to counsel its mastery. On the contrary, emotion as understood in the writing of this book is intrinsic to every experience, is a factor in all conduct. Emotion thus broadly conceived is fused with thinking - for the most part harmoniously-in the healthy, competent individual. (p. 5)

In this paradigm of social adjustment-as-health, active work was demanded to understand each student's emotions and support their proper group participation. While the potential for maladjustment was now assigned to everyone (Rose, 1990), its threat was particularly localized in students newly classified as not-college-bound (Mead, 1940; see Cohen, 1983; Lagemann, 2000). The Mathematics in General Education report (PEA, 1940) devoted a mammoth 68-page section to "Understanding the Student and Evaluating His Growth" and borrowed a new tool from fields of personality psychology, abnormal psychology, adolescent studies, sociology, and physiology: the case study. A sample case study identifying the "role of mathematics in Paul's personality" (PEA, 1940 , p. xiii) diagnosed his "superstitious attitude" towards certain numbers and geometric forms as common to children and "primitive people... throughout the history of the race" (p. 270). The prescribed solution was instruction directly addressing this "emotional charge in connection with subject-matter that is in itself so apparently nonemotional" (p. 271). In regulating that 'emotional charge,' student attitudes toward mathematics learning were taken as leverage points to adjust their overall intellectual and social development. The difference was not merely recognized but produced: case studies projected individuals onto a scale that reinstalled 'primitive civilizations' as lower anchors on a developmental path toward healthier relationships with school mathematics, self, peers, and democratic society.

In sum, mental hygiene discourses contributed to stabilizing school mathematics, while splitting it into ever-finer levels of targeted intervention. By now, critiques of ability tracking and rank ordering may appear well worn. Yet, it is crucial to note how curricular stratification and individualizing distinctions accompanied calls to minister to the shared (yet differentiated) humanity of students by offering tiered supports to bring them closer to norms of health and social adjustment. Diagnosing needs was now a dynamic site for recruiting teacher sympathies, improving well-being, and generating interest for mathematics as a driver of self-development, scientific progress, and democratic flourishing - a fact that demands closer scrutiny of recent reforms seeking once again to distinguish and prioritize students' mental health, well-being, and identity development. 


\section{Connecting with the present and concluding remarks}

Students' overall physical fitness and health are important prerequisites for high academic performance, and social and emotional well-being. There is strong evidence that participating in physical activity reduces depression and anxiety disorders, and boosts self-esteem (Organization for Economic Cooperation and Development [OECD]. (2017), p. 11)

Up to now, we have argued that shifting discourses of health and pathology were not peripheral to school mathematics but constitutive of institutional, pedagogical, and research routines that order possibilities for thought and action in mathematics education today. And, despite our focus on US histories, varied truth claims about physical and mental health appear in transnational discourses like the OECD's Program for International Student Assessment (PISA) (see epigraph). In this final section, we summarize our key claims by elaborating connections with themes in mathematics education research that both include and exceed explicit concerns with COVID-19. Our aim, again, is not to discount health concerns but to restore some of the historical tethers (Latour, 2004) binding school mathematics to health discourses in ways that continue to divide and exclude children today.

To start, early 19th-century concerns of disrupting a mind-body-spirit balance challenged the cold rationality of a disembodied mind, demanding new modes of fostering healthy citizens. Theories of heritable, modifiable differences posited education as a key site for planning the future by properly directing childhood malleability-in part by addressing health concerns (e.g., insanity) through school mathematics. In weighing the potential injuries and restorative effects of directing mathematics instruction at the nation's future citizenry, efforts to improve the health of "all classes" reconfigured sex-based and racialized hierarchies. Current reforms also presume relations of school mathematics and student health—now visible as comparative metrics of nations' mathematics literacy and their physical, mental, and social well-being (e.g., OECD, 2019). Rather than treating mathematics learning as a matter-of-fact driver of healthy decision making, scholars have begun to rethink this as a matter of concern resting on inherited premises of the child's (and state's) vulnerability and uneven distributions of reason across social categories (Diaz, 2017; Popkewitz, 2004; Ziols, 2019). While the circumstances, emphases, and scope of health discourses have undeniably changed, strategies to protect children from harm persist in projecting populations at varying distances from dis/embodied notions of reasoningnow locating the underachieving as potential threats to the nation's physical and economic health (Valero, 2017).

Later in the nineteenth century, the scientization of hygiene rank-ordered pupils and differentiated the mathematical and health needs of children and racialized populations. On the one hand, students were to be protected against unhappiness, ill-suited pedagogies, and subject-specific pathologies (e.g., arithmomania). On the other hand, children were assigned differing risks and potentials for self-development based on presumed effects of heredity, environment, sex, race, and ability-risks and potentials calibrated in segregated and colonial instruction claiming to improve the health and hygiene of target groups. Today, clinical techniques and subject-specific pathologies (e.g., dyscalculia) take new forms alongside differential and often racialized, nationalized, classed, and gendered assignments of harm and trauma (de Freitas \& Sinclair, 2016; Diaz, 2021; Valero, 2018; Ziols, 2019). Notions of mathematical dis/ability, mathematics anxiety, and mathematical mindset array students from normal to pathological (Brunila \& Valero, 2018; de Freitas \& 
Sinclair, 2016; Diaz, 2021; Yolcu \& Popkewitz, 2019; Ziols, 2019). School mathematics is not merely about learning mathematics (Popkewitz, 2004), but also about instilling coping strategies to improve health, optimize happiness, and avoid subject-specific dangers via diagnostic norms and pedagogical prescriptions that simultaneously universalize and divide.

Finally, mental hygiene preoccupations in the 1930s and 1940s envisioned the maladjusted student as requiring clinical understanding, ability grouping, and therapeutic pedagogies to foster mathematics appreciation. By directing the teacher's gaze toward students pronounced as most in need of sympathy, school mathematics was to rectify threats to the social order and challenge orthodoxies by proving those previously excluded could be reformed and "safely" integrated into schooling and democratic society. Similar hopes and fears about mental health and social inclusion appear today, albeit within distinct configurations. For example, mathematics identity is one among varied constructs that posit individuals and populations as differentially vulnerable to negative effect or alienation from a given school subject and as requiring tailored forms of protection, therapy, surveillance, or cultivation (Chronaki \& Kollosche, 2019; Ziols, 2019). However, in contrast with past mental hygiene discourses, mathematics identity is now often explicitly assigned to social categories (e.g., race, gender, and class) as foundational to truth claims about which kind(s) of school mathematics will be relevant, engaging, or empowering, and for whom.

Present calls to either confront pandemic-related crises or return to a new 'normal' carry reverberations from the past that raise important questions. If health appears a self-evident lens for filtering aims and methods of mathematics instruction, then how might we engage the historical traces of these strategies? How might we think otherwise if efforts to promote health-precisely by challenging mathematics as something cold, rational, abstract, and disconnected from the body and body politic - are not new, but long-standing participants in the perpetuation of all-too-familiar injuries and harms?

In closing, school mathematics is again called to reduce traumas and injuries by attending to educational and health inequities that exceed and include concerns with COVID-19. We do not argue that attention to disease or disparities is somehow ill advised or unwarranted. Rather, we have drawn scrutiny to the conditions of possibility that make health appear differently intelligible and actionable through school mathematics, such as premises of preserving national health via superior reasoning, prioritizing populational health needs, and promoting mental health and social adjustment. Our history of the present denaturalizes foundational assumptions linking the improvement of well-being to proper engagement with school mathematics-assumptions embedded in research and pedagogical practices that may inadvertently pathologize diversity, differentially surveil bodies, and normalize effect. Thankfully, the past is never totalizing or determinative. We hope to have articulated a few entry points for transnational analyses and a broader conversation about possibilities of addressing old and new problems amplified by COVID-19 during an undeniably difficult and unprecedented historical present.

\section{References}

"Account of the system of infant schools: Subjects of instruction in an infant school" (1826). American Journal of Education, 1(3), 129-134.

Altschuler, S. (2012). From blood vessels to global networks of exchange: The physiology of Benjamin Rush's early republic. Journal of the Early Republic, 32(2), 207-231. 
Anderson, J. D. (1988). The education of Blacks in the South, 1860-1935. University of North Carolina Press.

Anderson, W. (2006). Colonial pathologies: American tropical medicine, race, and hygiene in the Philippines. Duke University Press.

Baker, B. M. (2013). William James, sciences of mind, and anti-imperial discourse. Cambridge University Press.

Bakker, A., \& Wagner, D. (2020). Pandemic: Lessons for today and tomorrow? Educational Studies in Mathematics, 104(1), 1-4.

Barclay, J. L. (2014). 'The greatest degree of perfection': Disability and the construction of race in American Slave Law. South Carolina Review, 46(2), 27-43.

Barnes, D., Kobett, B., Shih, J., Bush, S., \& Teague, D. (2020, April 1). Using Math to Make Sense of Our World: Pandemics, Viruses, and Our Actions [Webinar]. In 100 Days of Professional Learning. Retrieved from: https://www.nctm.org/100-Days-of-Professional-Learning

Bennett, T., Dodsworth, F. M., Noble, G., Poovey, M., \& Watkins, M. E. (2013). Habit and habituation: Governance and the social. Body \& Society, 19(2-3), 3-29.

Berry III, R. Q. (2021). 2021 Founders lecture: Examining mathematics education reforms' impact on historically excluded learners. Investigations in Mathematics Learning, 1-14.

Betz, W. (1923). The confusion of objectives in secondary mathematics. The Mathematics Teacher, 16(8), 449-469.

Bidwell, J. K., \& Clason, R. G. (1970). Readings in the history of mathematics education. National Council of Teachers of Mathematics.

Borba, M. (2021). The future of mathematics education since COVID-19: Humans-with-media or humans-with-non-living-things. Educational Studies in Mathematics. https://doi.org/10.1007/ s10649-021-10043-2

Brigham, A. (1833). Remarks on the influence of mental cultivation and mental excitement upon health. Marsh, Capen, \& Lyon.

Brunila, K., \& Valero, P. (2018). Anxiety and the making of research(ing) subjects in neoliberal academia. Subjectivity, 11(1), 74-89.

Bullock, E. (2020). More than just potential: Troubling success counternarratives in mathematics education research. In C. A. Grant, A. N. Woodson, \& M. J. Dumas (Eds.), The future is Black: Afropessimism, fugitivity, and radical hope in education (pp. 117-126). Routledge.

Bulmer, M., Bales, K., \& Sklar, K. K. (1991). The social survey in historical perspective 1880-1940. Cambridge University Press.

Burnham, W. H. (1909). The scientific study of hygiene. The Pedagogical Seminary, 16(4), 437-441.

Burnham, W. H. (1911). Arithmetic and school hygiene. The Pedagogical Seminary, 18(1), 54-73.

Burnham, W. H. (1924). The normal mind: An introduction to mental hygiene and the hygiene of school instruction. D. Appleton.

Chronaki, A., \& Kollosche, D. (2019). Refusing mathematics: A discourse theory approach on the politics of identity work. ZDM-Mathematics Education, 51(3), 457-468.

Cohen, S. (1983). The mental hygiene movement, the development of personality and the school: The medicalization of American education. History of Education Quarterly, 23(2), 123-149.

Cohen, P. C. (1999). A calculating people: The spread of numeracy in early America. Routledge.

Coloma, R. S. (2009). "Destiny has thrown the Negro and the Filipino under the tutelage of America": Race and curriculum in the age of empire. Curriculum Inquiry, 39(4), 495-519.

National Council of Teachers of Mathematics (NCTM) \& National Council of Supervisors of Mathematics (NCSM) (2020). Moving forward: Mathematics learning in the era of COVID-19. Retrieved from: https://www.nctm.org/uploadedFiles/Research_and_Advocacy/NCTM_NCSM_Moving_Forward.pdf

Crary, J. (1988). Techniques of the observer. October, 45, 3-35.

d'Ambrosio, U. (2003). Stakes in mathematics education for the societies of today and tomorrow. In D. Coray, F. Furinghetti, H. Gispert, B. Hodgson, \& G. Schubring (Eds.), One hundred years of l'Enseignement Mathématique (pp. 301-316). Monograph no. 39. Geneva.

Danziger, K. (1997). Naming the mind. Sage Publications.

Davis, J., \& Martin, D. B. (2018). Racism, assessment, and instructional practices: Implications for mathematics teachers of African American students. Journal of Urban Mathematics Education, 11(1 \& 2), 45-68.

de Freitas, E., \& Sinclair, N. (2016). The cognitive labour of mathematics dis/ability: Neurocognitive approaches to number sense. International Journal of Educational Research, 79, 222-230.

de Freitas, E. (2017). Biosocial becomings: Rethinking the biopolitics of mathematics education research. In A. Chronaki (Ed.), Proceedings of the ninth International Mathematics Education and Society Conference. University of Thessaly Press. 
Diaz, J. D. (2021). Inheriting the historical limits of inclusion: When making a mathematical mindset is not enough. Philosophy of Mathematics Education Journal, 37. Retrieved from: http://socialsciences. exeter.ac.uk/education/research/centres/stem/publications/pmej/pome37/index.html

Diaz, J. D. (2017). A cultural history of reforming math for all: The paradox of making in/equality. Routledge.

Domosh, M. (2015). Practising development at home: Race, gender, and the 'development' of the American South. Antipode, 47, 915-941.

Dwight, T. (1835). The school-master's friend, with the committee-man's guide: Containing suggestions on common education, modes of teaching and governing. Roe Lockwood.

Dykema, K., Nguyen, F., Song, E., Jessup, N. (2020, July 28). Understanding the mental toll: Signals and strategies for supporting our teachers and students [webinar]. In 100 days of professional learning. Retrieved from: https://www.nctm.org/100-Days-of-Professional-Learning

"Educating Children to Death.” (1837, January). American Annals of Education (1830-1839), 7, 15. Retrieved from https://search.proquest.com/docview/89619982?accountid=11226

Engelbrecht, J., Borba, M. C., Llinares, S., \& Kaiser, G. (2020). Will 2020 be remembered as the year in which education was changed? ZDM-Mathematics Education, 52(2), 821-824.

Foucault, M. (1972). The archaeology of knowledge (A. M. Sheridan Smith, Trans.). Pantheon.

Foucault, M. (1988). Madness and civilization: A history of insanity in the age of reason (R. Howard, Trans.). Vintage Books.

Foucault, M. (1990). The history of sexuality (Vol. 1) (R. Hurley, Trans.). Vintage Books.

Foucault, M. (1991). The Foucault effect: Studies in governmentality. University of Chicago Press.

Foucault, M. (2003). "Society must be defended”: Lectures at the Collège de France 1975-1976 (D. Macey, Trans.). Picador.

Gentleman, F. (1913). The purpose and the content of a course of mathematics for technical and manual training high schools. The Mathematics Teacher, 6(1), 22-40.

Givens, J. R. (2020). Literate slave, fugitive slave: A note on the ethical dilemma of black education. In C. A. Grant, A. N. Woodson, \& M. J. Dumas (Eds.) The future is Black: Afropessimism, fugitivity, and radical hope in education (pp. 22-30). Routledge.

Gonzalez, G. G. (1985). Segregation of Mexican children in a southern California city: The legacy of expansionism and the American Southwest. Western Historical Quarterly, 16(1), 55-76.

Goodrich, S.G. (1818). The child's arithmetic, being an easy and cheap introduction to Daboll's, Pike's, and White's, and other arithmetics. Samuel G. Goodrich.

Green, J. L. (1918). Character-building content of arithmetic. The Mathematics Teacher, 11(1), 36-41.

Howell, H. B. (1914). A foundational study in the pedagogy of arithmetic. Macmillan.

Jenkins, A. (2010). Mathematics and mental health in early nineteenth-century England. BSHM Bulletin, 25(2), 92-103.

Joint Commission of the Mathematical Association of America [MAA] and the National Council of Teachers of Mathematics [NCTM] (1940). The place of mathematics in secondary education: The final report. Bureau of Publications, Teachers College, Columbia University.

Jones, T. J. (1917). Negro education: A study of the private and higher schools for colored people in the United States. Government Printing Office.

Kanes, C., Morgan, C., \& Tsatsaroni, A. (2014). The PISA mathematics regime: Knowledge structures and practices of the self. Educational Studies in Mathematics, 87(2), 145-165.

Kett, J. F. (1971). Adolescence and youth in nineteenth-century America. The Journal of Interdisciplinary History, 2(2), 283-298.

Kim, S., Seo, Y. B., \& Jung, E. (2020).Prediction of COVID-19 transmission dynamics using a mathematical model considering behavior changes. Epidemiology and Health, 42. https://doi.org/10.4178/epih. e2020026

Kirchgasler, K. L. (2018). Moving the lab into the field: The making of pathologized (non) citizens in US science education. Curriculum Inquiry, 48(1), 115-137.

Kollosche, D. (2016). Criticising with Foucault: Towards a guiding framework for socio-political studies in mathematics education. Educational Studies in Mathematics, 91(1), 73-86.

Lagemann, E. C. (2000). An elusive science: The troubling history of education research. University of Chicago Press.

Lammers, J., Crusius, J., \& Gast, A. (2020). Correcting misperceptions of exponential coronavirus growth increases support for social distancing. Proceedings of the National Academy of Sciences, 117(28), $16264-16266$.

Larnell, G. V., Bullock, E. C., \& Jett, C. C. (2016). Rethinking teaching and learning mathematics for social justice from a critical race perspective. Journal of Education, 196(1), 19-29. 
Latour, B. (2004). Why has critique run out of steam? From matters of fact to matters of concern. Critical Inquiry, 30(2), 225-248.

Leak, D., Patrick, L. \& Champagne, Z. (2021, April 12). Understanding and reframing "learning loss" in mathematics: Goals, policies, and practices for strengths-oriented and equitable solutions. In 100 Days of Professional Learning. Retrieved from: https://www.nctm.org/100-Days-of-ProfessionalLearning

Leyva, L. A. (2021). Black women's counter-stories of resilience and within-group tensions in the white, patriarchal space of mathematics education. Journal for Research in Mathematics Education, 52(2), 117-151.

Llewellyn, A. (2018). Manufacturing the mathematical child: A deconstruction of dominant spaces of production and governance. Routledge.

Lundin, S. (2012). Hating school, loving mathematics: On the ideological function of critique and reform in mathematics education. Educational Studies in Mathematics, 80(1-2), 73-85.

Martin, D. B. (2019). Equity, inclusion, and antiblackness in mathematics education. Race Ethnicity and Dducation, 22(4), 459-478.

McLeod, J., \& Paisley, F. (2018). The modernization of colonialism and the educability of the 'native': Transpacific knowledge networks and education in the interwar years. History of Education Quarterly, 56(3), 473-502.

Mead, M. (1940). Social change and cultural surrogates. The Journal of Educational Sociology, 14(2), 92-109.

Molina, N. (2006). Fit to be citizens? Public health and race in Los Angeles, 1879-1939. University of California Press.

Monroe, W. S., \& Colburn, W. (1912). Warren Colburn on the teaching of arithmetic together with an analysis of his arithmetic texts [Continued]. The Elementary School Teacher, 12(10), 463-480.

Nieves, B. (2014). Imagined geographies and the construction of the campesino and jíbaro identities. In B. van Wyk, \& D. Adeniji-Neill (Eds.), Indigenous concepts of education: Toward elevating humanity for all learners (pp. 31-41). Palgrave Macmillan.

Organization for Economic Cooperation and Development [OECD]. (2017). PISA 2015 Results (Volume III). Students' Well-Being. OECD Publishing. Retrieved from: https://doi.org/10.1787/19963777

Organization for Economic Cooperation and Development [OECD]. (2019). PISA 2018 assessment and analytical framework. PISA, OECD Publishing. Retrieved from: https://doi.org/10.1787/b25ef ab8-en

Pais, A. (2011). Criticisms and contradictions of ethnomathematics. Educational Studies in Mathematics, 76(2), 209-230.

Pais, A. (2013). An ideology critique of the use-value of mathematics. Educational Studies in Mathematics, 84(1), 15-34.

Pais, A. (2019). Mathematics, capitalism and biosocial research. Educational Studies in Mathematics, 101(3), 373-386.

Pais, A., \& Valero, P. (2012). Researching research: Mathematics education in the political. Educational Studies in Mathematics, 80(1-2), 9-24.

Paulet, A. (2007). To change the world: The use of American Indian education in the Philippines. History of Education Quarterly, 47(2), 173-202.

Petrina, S. (2006). The medicalization of education: A historiographic synthesis. History of Education Quarterly, 46(4), 503-531.

Popkewitz, T. S. (2004). The alchemy of the mathematics curriculum: Inscriptions and the fabrication of the child. American Educational Research Journal, 41(1), 3-34.

Popkewitz, T. S. (2008). Cosmopolitanism and the age of school reform: Science, education, and making society by making the child. Routledge.

Popkewitz, T. S. (Ed.) (1987). The formation of school subjects: The struggle for creating an American institution. Falmer Press.

Price, A. (1960). A pioneer of scientific education George Combe (1788-1858). Educational Review, 12(3), 219-229.

Progressive Education Association [PEA]. (1940). Mathematics in general education. Commission on the secondary school curriculum of the Progressive Education Association. D. Appleton-Century Company.

Rabinow, P., \& Rose, N. (2006). Biopower today. BioSocieties, 1(2), 195-217.

Rapeer, L. W. (Ed.). (1917). Teaching elementary school subjects. Charles Scribner's Sons.

Reel, E. (1904). Report of superintendent of Indian schools: Annual reports of the Department of the Interior for the fiscal year ended June 30, 1903. Government Printing Office.

Rose, N. (1990). Governing the soul: The shaping of the private self. Taylor \& Frances/Routledge. 
Santana, M., Nussbaum, M., Claro, S., Piza, S., Imbarack, P., \& Loeb, S. (2021). Let's spend time together: Text messaging parents to help math-anxious students. Journal for Research in Mathematics Education, 52(2), 189-212.

Schaaf, W. L. (1930). Mathematics and world history. The Mathematics Teacher, 23(8), 496-503.

Schuller, K., \& Gill-Peterson, J. (2020). Introduction: Race, the state, and the malleable body. Social Text, 38(2), 1-17.

Schuller, K. (2018). The biopolitics of feeling: Race, sex, and science in the nineteenth century. Duke University Press.

Setran, D. (2003). "From morality to character": Conservative progressivism and the search for civic virtue, 1910-1930. Paedagogica Historica, 39(4), 435-456.

Soland, J., Kuhfeld, M., Tarasawa, B., Johnson, A., Ruzek, E., \& Liu, J. (2020, May 27). The impact of COVID-19 on student achievement and what it may mean for educators. Retrieved from: https:// www.brookings.edu/blog/brown-center-chalkboard/2020/05/27/the-impact-of-covid-19-on-stude nt-achievement-and-what-it-may-mean-for-educators/

Sowell, J. W. (1905). Arithmetic. American Annals of the Deaf, 50(3), 279-293.

Speer, W. W. (1897). Elementary arithmetic. Ginn.

Spengler, O. (1932). The decline of the west (C.F. Atkinson, Trans.). Modern Library.

Spurzheim, J. G. (1836). Observations on the deranged manifestations of the mind, or insanity. Marsh, Capen \& Lyon.

Stanic, G. M. (1986). The growing crisis in mathematics education in the early twentieth century. Journal for Research in Mathematics Education, 17(3), 190-205.

Stephan, M., Register, J., Reinke, L., Robinson, C., Pugalenthi, P., \& Pugalee, D. (2021). People use math as a weapon: Critical mathematics consciousness in the time of COVID-19. Educational Studies in Mathematics, 1-20.

Tate, W. F. (2008). Putting the 'urban' in mathematics education scholarship. Journal of Urban Mathematics Education, $11(1$ \& 2), 26-30.

Theobald, H. C. (1907). The Filipino teacher's manual. World Book Company.

Thorndike, E. L. (1922). The psychology of arithmetic. Columbia University.

Todd, J. (1998). Physical culture and the body beautiful: Purposive exercise in the lives of American women, 1800-1870. Mercer University Press.

TODOS. (2020). The mo(ve)ment to prioritize antiracist mathematics: Planning for this and every school year. Retrieved from: https://www.todosmath.org/assets/The $\% 20$ Movement $\% 20$ to $\% 20$ Prioritize\% 20Antiracist\%20Mathematics\%20Ed\%20by\%20TODOS\%20June\%202020.edited.pdf

Tolley, K. (2002). The science education of American girls: A historical perspective. Routledge.

Tomlinson, S. (2005). Head masters: Phrenology, secular education, and nineteenth-century social thought. University of Alabama Press.

U.S. Office of Indian Affairs. (1908). Report of the commissioner of Indian affairs to the secretary of the interior. Government Printing Office.

Valero, P. (2018). Human capitals: School mathematics and the making of the homus oeconomicus. Journal of Urban Mathematics Education, $11(1$ \& 2), 103-117.

Valero, P. (2017). Mathematics for all, economic growth, and the making of the citizenworker. In T. S. Popkewitz, J. Diaz, \& C. Kirchgasler (Eds.), A political sociology of educational knowledge: Studies of exclusions and difference (pp. 117-132). Routledge.

Wagner, D., Bakker, A., Meaney, T., Mesa, V., Prediger, S., \& Van Dooren, W. (2020). What can we do against racism in mathematics education research? Educational Studies in Mathematics, 104(3), 299-311.

Watkins, W. H. (2001). The White architects of Black education: Ideology and power in America, 18651954. Teachers College Press.

Weheliye, A. G. (2014). Habeas viscus. Duke University Press.

Woodson, C. G. (1919). The education of the Negro prior to 1861: A history of the education of the colored people of the United States from the beginning of slavery to the civil war. Association for the Study of Negro Life and History.

Yocum, A. D. (1914). Mathematics as a means to culture and discipline. The Mathematics Teacher, 6(3), 135-157.

Yolcu, A. (2019). Research on equitable mathematics teaching practices: Insights into its divergences and convergences. Review of Education, 7(3), 701-730.

Yolcu, A., \& Popkewitz, T. S. (2019). Making the able body: School mathematics as a cultural practice. ZDM-Mathematics Education, 51(2), 251-261. 
Yoon, H., Byerley, C. O., Joshua, S., Moore, K., Park, M. S., Musgrave, S., Valaas, L., \& Drimalla, J. (2021). United States and South Korean citizens' interpretation and assessment of COVID-19 quantitative data. The Journal of Mathematical Behavior, 62.

Zachary, C. B., \& Lighty, M. (1940). Emotion and conduct in adolescence. Commission on Secondary School Curriculum. D. Appleton-Century Company.

Ziols, R. J. (2019). "Revolution, reform, and research" for a healthier, more vital republic? A post-foundational geography of U.S. school mathematics. (Doctoral thesis, University of Wisconsin-Madison, Madison, WI). Retrieved from: https://search.proquest.com/docview/2331266649?accountid=11226.

Publisher's note Springer Nature remains neutral with regard to jurisdictional claims in published maps and institutional affiliations. 